\title{
Effects of Lactococcus lactis sp. on Nutritional Value of Formulated Non-dairy Complementary Foods from Irish Potato, Mungbean, Red Kidney Bean and Papaya
}

\author{
B.D.S. Dangang ${ }^{1}$, N.F. Zambou, ${ }^{1, *}$, R. Agrawal ${ }^{2}$, A.F. Fonteh ${ }^{3}$ \\ ${ }^{1}$ Department of Biochemistry, University of Dschang, Cameroon \\ ${ }^{2}$ Microbiology and Fermentation Technology Department, Central Food Technological Research Institute (CFTRI), India \\ ${ }^{3}$ Department of Agronomy and Agricultural Sciences, University of Dschang, Cameroon \\ *Corresponding author: fzambou@yahoo.fr
}

\begin{abstract}
To improve the child nutrition, complementary foods were formulated using the following components: Lactococcus lactis sp. (Lc. lactis sp.) strain, 20\% red kidney bean (Phaseolus vulgaris L.), 60\% mung bean (Vigna radiate), $10 \%$ irish potato (Solanum tuberosum), and $10 \%$ ripe fresh papaya (Carica papaya) fruits. The formulation compounds were mixed and then inoculated by different concentrations of the bacterial strain $0 \mathrm{CFU} \mathrm{mL}^{-1}$ (control diet); $1 \times 10^{6} \mathrm{CFU} \mathrm{mL}^{-1}$ (Diet 1) and $2 \times 10^{6} \mathrm{CFU} \mathrm{mL}^{-1}$ (Diet 2). The effects of bacteria concentrations on $\mathrm{pH}$, final viable cell counts, titratable acidity, Water Holding Capacity (WHC), antioxidant activity, viscosity and proximate composition were investigated. Results showed that diet 2 had the lower $\mathrm{pH}$ (4.50), highest final viable cell counts $\left(3.9 \times 10^{9} \mathrm{CFU} \mathrm{mL}{ }^{-1}\right)$. Bacteria culture increased the WHC and viscosity of diets. The free radical scavenging activity was significantly $(\mathrm{p}<0.01)$ higher in diet $2(57.33 \pm 0.66 \%)$ when compared to the control diet $(31.37 \pm$ $0.25 \%$ ). Crude protein, fat, total energy and mineral contents increased with starter cultures. The results of this study showed that $L c$. lactis sp. strain improved the nutritional value of fermented foods 1 and 2 . Diet 2 showed the best results in term of nutritional values, mineral contents and may be recommended as complementary food for children.
\end{abstract}

Keywords: Probiotic complementary food, fermentation, water holding capacity, antioxidant activity, viscosity, proximate composition

Cite This Article: B.D.S. Dangang, N.F. Zambou, A.F. Fonteh, and R. Agrawal, "Effects of Lactococcus lactis sp. on Nutritional Value of Formulated Non-dairy Complementary Foods from Irish Potato, Mungbean, Red Kidney Bean and Papaya.” American Journal of Food and Nutrition, vol. 6, no. 1 (2018): 1-8. doi: 10.12691/ajfn-6-1-1.

\section{Introduction}

Malnutrition is a significant underlying factor in children mortality accounting for approximately $50 \%$ of death among under-five children. In developing countries, about $25 \%$ of children are moderately or severely malnourished (underweight and/or stunted) [1]. In Cameroon, $32 \%$ of children under the age of five are stunted, $16 \%$ are underweight and $7 \%$ are wasted. $45 \%$ with aged of fifteen, and above are overweight or obese, and $11 \%$ of children are born with low birth weight [2,3]; at least 45,000 children die annually due to malnutrition [4].

Malnutrition mostly results from the quality of the complementary food given to children, because it is often nutritionally unbalanced. Several authors reported that in many developing countries, the complement foods given to children were made either only with tubers or only with cereals which could quickly affect the health of children. Despite abundant global food supplies, widespread malnutrition persists in Cameroon. Appropriate feeding practices are essential for the growth and development of a child [5]. The primary approach to this is the development of functional food, which has considerably gained consumer's interest over the last decade.

Functional food is a part of an everyday diet and can offer health benefits and to reduce the risk of chronic disease beyond the widely accepted nutritional effects. The functional food comprises: (i) conventional foods containing naturally occurring bioactive compounds (e.g., dietary fiber), (ii) diet enriched with bioactive substances (e.g., probiotics, antioxidants), and (iii) synthesized food ingredients introduced to traditional food (e.g., prebiotics) [6].

The range of food products containing probiotic strains is wide and still growing. The main products existing in the market are dairy-foods. However, recently several raw materials have been significantly extensively investigated to determine if they are suitable substrates to produce novel non-dairy probiotic microorganisms, and it has been found that traditionally fermented food may contain viable probiotic microorganisms [7]. Probiotic food products should contain at least $10^{7}$ live bacteria per gram or per milliliter for better efficacy in regulating beneficial effects $[8,9]$. The use of isolated strains during cereal dough fermentation was reported to (1) minimise dry matter loss, (2) enhance control over the fermentation step, 
(3) enhance acid production or reduction in $\mathrm{pH}$ levels, (4) contribute to aroma and taste formation, as well as to increase the overall acceptability of the product and (5) enhance the nutritional quality of the product through the formation of preservative compounds or a reduction in mycotoxins, such as aflatoxins and fumonisins [10,11]. The challenge in fermenting such grains is represented by the necessity to combine good technology and sensory properties with nutritional/health benefits.

This work aimed to contribute to the reduction of malnutrition during infancy using local raw available food such as mungbean, irish potato, red kidney bean, papaya, Lc. Lactis sp. strain which some probiotic properties have already evaluated in vitro and inexpensive technology to prepare a probiotic fermented complementary food.

\section{Materials and Methods}

\subsection{Collection of Samples}

Dry red kidney beans (Phaseolus vulgaris) were purchased from a local market of Dschang, Cameroon. Dry dehulled mungbeans (Vigna radiate), potatoes (Solanum tuberosum), and papaya (Carica papaya) were purchased from a local supermarket in Mysore, India.

\subsection{Microorganisms and Growth Conditions}

Lc. lactis sp. strain used in this work was obtained from the laboratory of Biochemistry, Medicinal plant, Nutrition and Food science (LABPMAN) of the University of Dschang-Cameroon which was isolated from fermented maize beverage “sha'a”. Before experimental use, Lc. lactis sp. culture was propagated (1\%, v/v) twice in M17 broth and incubated at $37^{\circ} \mathrm{C}$ for $18 \mathrm{~h}$ without agitation. $5 \mathrm{~mL}$ was collected and centrifuged $\left(8,000 \mathrm{~g}, 10 \mathrm{~min}, 4{ }^{\circ} \mathrm{C}\right)$, cells were washed twice with sterile physiological solution and resuspended in $2.5 \mathrm{~mL}$ of the same solution.

\subsection{Formulation and Preparation}

The complementary food was formulated according to the recommended daily allowance to maintain the nutrient composition of the composite paste close to the WHO/FAO standard values for complementary foods, i.e., $70 \%$ carbohydrates, $16 \%$ proteins, $7 \%$ lipid, $2 \%$ ash, and $5 \%$ fibers [12]. The final proportions used were $20 \%$ red kidney bean, $60 \%$ mung bean, $10 \%$ irish potato, and $10 \%$ ripe fresh papaya fruits.

Red kidney beans were soaked in distilled water for 18 $\mathrm{h}$, removed and dehulled manually; dehulled raw mungbean was soaked in distilled water for $2 \mathrm{~h}$; Irish potato was cleaned, washed, peeled and diced. Papaya fruit was washed, peeled and diced. Raw materials were mixed with $50 \mathrm{~mL}$ of distilled water and ground using Meenũmix model M-86 (Meen Equipment, India) during $2 \mathrm{~min}$. $200 \mathrm{~mL}$ of distilled water was added progressively to the paste, homogenized and precooked for 15 min on hotplate. $0.5 \mathrm{~g}$ of salt was also added to the paste. Into three $250 \mathrm{~mL}$ Erlenmeyer each, $100 \mathrm{~mL}$ of paste was introduced, cooked for $1 \mathrm{~h}$ to destroy anti nutritional factors and sterilized by autoclaving at $121^{\circ} \mathrm{C}$ for $15 \mathrm{~min}$.

\subsection{Inoculations}

When the pastes reached room temperature, they were inoculated with different concentrations of culture $1 \times 10^{6}$ CFU mL ${ }^{-1}$ for diet 1 and $2 \times 10^{6} \mathrm{CFU} \mathrm{mL}^{-1}$ for diet 2 . Pastes were incubated at selected temperature for $18 \mathrm{~h}$ in adequate conditions. Uninoculated paste treated in the same way was used as a control.

\subsection{Microbial Counts}

Cell viability was determined by the plate dilution method using M17 agar. Serial dilutions of each fermented food sample were plated in duplicate, and the plates were incubated at $37{ }^{\circ} \mathrm{C}$ for $24-48 \mathrm{~h}$. The results were expressed as colony forming units per milliliter $\left(\mathrm{CFU} \mathrm{mL} \mathrm{mL}^{-1}\right.$ ). The cell morphology (Figure 1) was examined using a light microscope (CX, Olympus, Tokyo, Japan) using oil immersion $(\times 100)$.

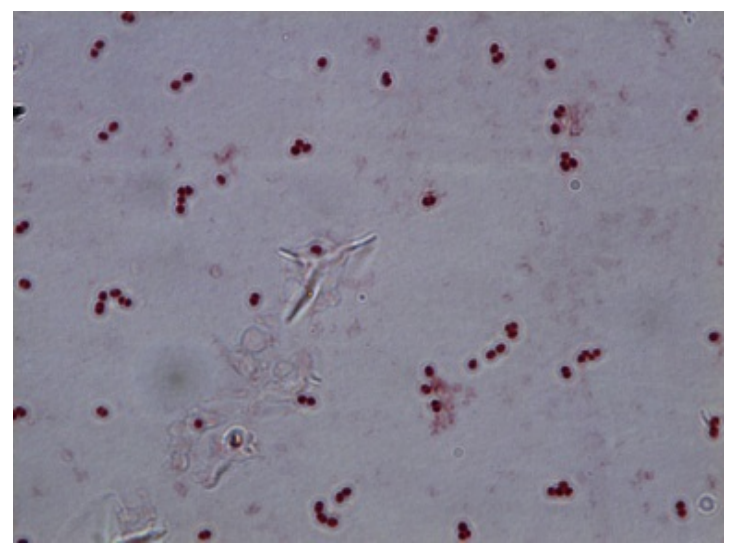

Figure 1. Cell morphology of Lc. Lactis sp.

\subsection{Effect of Cell concentrations on $\mathrm{pH}$ and Titratable Acidity}

Changes in $\mathrm{pH}$ were monitored after fermenting the paste using a $\mathrm{pH}$ meter (PHM61 Radiometer, Copenhagen, Denmark) with an Orion 9102 glass electrode (Orion Research, Boston, Mass., USA).

The titratable acidity values $\left({ }^{0} \mathrm{~T}\right.$, expressed as Thorner degree, ${ }^{0} \mathrm{~T}^{*} 0.009$ = lactic acid \%) of the different samples were analyzed according to the method of Li et al. [13].

All measurements were carried out in triplicate.

\subsection{Effect of Cell Concentrations on the Antioxidant Activity of the Probiotic Fermented Food}

$5 \mathrm{~g}$ of the fermented probiotic product was mixed with methanol and water mixture (1:1). The mixture was macerated using mortar and pestle for $15 \mathrm{~min}$, and the extract was collected in centrifuge tubes. The extract was centrifuged at $8000 \mathrm{rpm}$ for $20 \mathrm{~min}$ at $4^{\circ} \mathrm{C}$ and supernatant were collected in Eppendorf tubes. To $1 \mathrm{~mL}$ of supernatant, $1 \mathrm{~mL}$ of DPPH solution was added and mixed; this was kept for $30 \mathrm{~min}$ at room temperature.

The level of scavenged DPPH was monitored by the decrease in absorbance at $517 \mathrm{~nm}$. The percentage of scavenging activity was calculated as follows: 
Antioxidant activity $(\%)=\frac{\mathrm{A}_{0}-\mathrm{A}}{\mathrm{A}_{0}} \times 100$

$\mathrm{A}_{0}=$ Absorbance of the control

$\mathrm{A}=$ Absorbance of sample.

\subsection{Determination of Water Holding Capacity (WHC)}

WHC is defined as the ability of fermented food to hold all or part of its water. WHC of the samples was determined by the centrifugation method described by Isanga and Zhang [14] with slight modification. Fermented soymilk (30 g) was centrifuged (8000 g, $4{ }^{\circ} \mathrm{C}$ ) for $15 \mathrm{~min}$. The supernatant was collected, weighed, and WHC was calculated according to the following equation:

$$
\mathrm{WHC}(\%)=\left(1-\mathrm{W}_{1} / \mathrm{W}_{2}\right) \times 100
$$

Where: $\mathrm{W}_{1}=$ weight of supernatant after centrifugation (g); $\mathrm{W}_{2}$ = fermented food weight (g).

All measurements were carried out in triplicate.

\subsection{Rheological Analysis}

The rheological properties of fermented diets after $18 \mathrm{~h}$ incubation were investigated by using a rheometer (Anton Paar MCR 52, OstWldern, Germany). The rheometer consisted of parallel plate geometry (50 mm diameter), $1^{\circ}$ cone angle and the gap between the two plates was set to $2 \mathrm{~mm}$. The sample was placed into the rheometer equilibrated at $25^{\circ} \mathrm{C}$, and excess paste was removed. During measurements, sample temperature was kept constant at $25^{\circ} \mathrm{C}$ by a Peltier plate system attached to a water circulation unit. To ensure that all analyses were carried out within the linear viscoelastic region, oscillation stress amplitude sweeps were performed in the range of 0.003 to $100 \%$ strain. Based on these results, oscillation stresses for the samples were selected. Frequency sweep tests were performed at angular frequencies between 0.1 and $50(1 / \mathrm{s})$ with a target strain of $1 \times 10^{-4}(0.01 \%)$. Data were collected every $2 \mathrm{~s}$, and the complex viscosity (Pa.s) was monitored, resulting in pasting profile.

\subsection{Proximate Analysis}

The slurry was dried at $50^{\circ} \mathrm{C}$ for $24 \mathrm{~h}$ in a hot air oven. The dried slurry was milled into flour to pass through a 60 mesh wire screen and stored at $4^{\circ} \mathrm{C}$ for proximate analysis.

Proximate composition of diets was conducted as follows: Moisture, ash, and fat were analyzed using standard methods of analysis [15]. Crude protein was determined by the micro-Kjeldahl method with the conversion factor of $\mathrm{N} \times 6.25$. Carbohydrate content was estimated by subtracting the sum of percentages of moisture, crude fat, crude protein and ash contents from 100. Total energy was determined by the formula:

$$
\begin{aligned}
& \text { Total energy }(\mathrm{kcal} 100 \mathrm{~g}) \\
& \begin{aligned}
= & (\% \text { available carbohydrates } \times 4) \\
& +(\% \text { protein } \times 4)+(\% \text { fat } \times 9) .
\end{aligned}
\end{aligned}
$$

Micronutrients such as Potassium and Sodium contents were assessed by a flame spectrophotometer while
Calcium, Magnesium, Iron, and Zinc were analyzed using an atomic absorption spectrophotometer [16].

\subsection{Statistical Analysis}

Each parameter was analyzed in triplicate. Results are shown as means \pm standard deviations. Data were subjected to one-way ANOVA; pair-comparison of treatment means was obtained by Tukey's procedure at $\mathrm{p}<0.05$, using the Statistical software for Windows (GraphPad InStat).

\section{Results and Discussion}

\subsection{Effect of Cell Concentrations on pH Levels}

Table 1 showed the $\mathrm{pH}$ and titration acidity of diets after fermentation. The highest $\mathrm{pH}$ was observed in the control diet whereas the $\mathrm{pH}$ was low in inoculated diets. The $\mathrm{pH}$ of diet 1 was slightly higher than the safe, hygienic $\mathrm{pH}$ which is 4.0 to 4.5 [17]. The high $\mathrm{pH}$ of the control diet $(5.44>4.5)$ means that it has a slow acidification rate, and may favor the proliferation of spoilage and pathogenic microflora like Enterobacteriaceae and spore-forming Bacillus cereus [18,19]. The decrease in $\mathrm{pH}$ observed in inoculated diets was due to lactic acid fermentation, in fact during the fermentation process, there is a production of organic acids which will decrease the pH. Rozada-Sánchez et al. [20] reported similar result during evaluation of Bifidobacterium longum for the production of a potentially probiotic malt-based beverage respectively. Kim et al. [21] also observed decreasing of $\mathrm{pH}$ of fermented potato juices with $L$. casei.

The trend in total titratable acidity was directly opposite to the results observed for $\mathrm{pH}$. There was a gradual increase in overall acidity in function of cell concentrations. Control diet showed a lower value of titratable acidity whereas in inoculated diets this value was significantly higher $(\mathrm{p}<0.01)$ when compared to the control. It has been noted that the total acid percentage found in diet 2 was the highest percentage followed by diet 1 and control diet. These compounds should affect the value of titratable acidity.

Table 1. Effect of cell concentrations on $\mathrm{pH}$ after fermentation

\begin{tabular}{ccccc}
\hline $\begin{array}{c}\text { Food } \\
\text { samples }\end{array}$ & $\begin{array}{c}\text { Concentrations } \\
\left.(\mathrm{CFU} \mathrm{mL})^{-1}\right)\end{array}$ & Initial pH & $\mathrm{pH}$ & $\begin{array}{c}\text { Acidity } \\
\text { titration }\left({ }^{\circ} \mathrm{T}\right)\end{array}$ \\
\hline $\begin{array}{c}\text { Control } \\
\text { diet }\end{array}$ & 0 & $6.02 \pm 0.01$ & $5.44 \pm 0.01^{\mathrm{a}}$ & $29.75 \pm 0.35^{\mathrm{a}}$ \\
Diet 1 & $1 \times 10^{6}$ & $6.02 \pm 0.01$ & $4.66 \pm 0.02^{\mathrm{b}}$ & $37.00 \pm 1.41^{\mathrm{b}}$ \\
Diet 2 & $2 \times 10^{6}$ & $6.02 \pm 0.01$ & $4.50 \pm 0.01^{\mathrm{c}}$ & $42.00 \pm 0.00^{\mathrm{c}}$ \\
\hline
\end{tabular}

Data are means with standard deviations of triplicate values. Values not sharing a common superscript differ significantly.

\subsection{Effect of Cell Concentrations on Total Final Cell Count after Fermentation}

The changes in viable cell counts of Lc. lactis sp. in fermented foods are shown in Table 2. The viable cell counts in diets 1 and 2 increased significantly during 
fermentation $(\mathrm{p}<0.05)$ and reached almost $4 \times 10^{9} \mathrm{CFU} \mathrm{mL}^{-1}$ in diet 2 whereas not Lc. lactis sp. were found in control diet. These results are similar to those of Kim et al. [21] who observed the increase of viable cell of L. casei $\left(1.7 \times 10^{9} \mathrm{CFU} \mathrm{mL} \mathrm{mL}^{-1}\right)$ after $72 \mathrm{~h}$ fermentation at $37^{\circ} \mathrm{C}$ of fermented 'Haryoung' juice with initial inoculum $10^{6} \mathrm{CFU} \mathrm{mL} \mathrm{m}^{-1}$. Survival of probiotic strains in different food matrices throughout the shelf-life is crucial for their functioning. The minimum number of probiotic bacteria for preparation of fermented food is $10^{7}$ viable cells per gram or milliliter $[8,9]$ and minimum therapeutic dose per day is $10^{8}-10^{9}$ cells [22]. In this study, the concentration of Lc. lactis sp. obtained after fermentation is more than the minimum number of viable cells recommended.

Table 2. Effect of cell concentrations on final cell after fermentation

\begin{tabular}{lcc}
\hline Food samples & Concentrations $\left(\mathrm{CFU} \mathrm{mL}^{-1}\right)$ & Final cells $\left(\mathrm{CFU} \mathrm{mL} \mathrm{m}^{-1}\right)$ \\
\hline Control diet & 0 & 0 \\
Diet 1 & $1 \times 10^{6}$ & $1 \times 10^{9}$ \\
Diet 2 & $2 \times 10^{6}$ & $4 \times 10^{9}$ \\
\hline
\end{tabular}

Data are means of triplicate values.

\subsection{Effect of Cell Concentrations on Water Binding Capacity (WHC)}

Figure 2 showed the Water Holding Capacity of different diets. The WHC of diet $1(61.39 \pm 1.59 \%)$ and diet 2 $(62.68 \pm 1.94 \%)$ were significantly high $(\mathrm{p}<0.05)$ compared to the control diet $(51.94 \pm 2.53 \%)$. The differences observed between WHC of diets may be attributed to the different exopolysaccharides (EPS) amounts. In fact, during fermentation, lactic acid bacteria are capable of hydrolyzing food-plant carbohydrate to produce EPS which can interact with proteins present in the substrate and affect the WHC. Ferragut et al. [23]; Folkenberg et al. [24] reported that the interactions of EPS with proteins are fundamental in fermented milk and soymilk because of their effects on the microstructure and texture of this food. WHC values of this study are less compared to those found by $\mathrm{Li}$ et al. [25] in fermented soymilks which were ranged from $74.03 \%$ to $88.27 \%$. This may be due to the fact that soy milk is a very rich proteins-source.

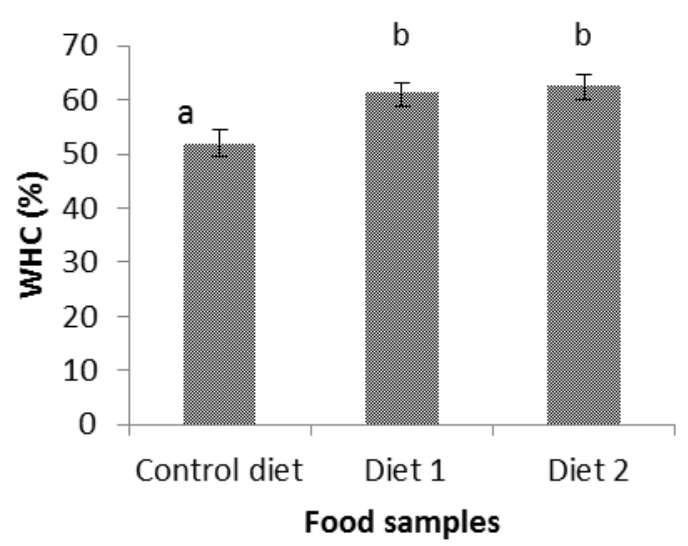

Data are means with standard deviations of triplicate values. Values not sharing a common superscript differ significantly.

Figure 2. Effects of Lc. lactis sp on WHC (\%) of diets

\subsection{Antioxidant Activity: Scavenging Effect on $\alpha, \alpha$-diphenyl- $\beta$-picrylhydrazyl (DPPH) Radicals}

There was a gradual increase in the antioxidant activities of the fermented products as the cell concentration increased (Figure 3). The inoculated diets demonstrated higher antioxidant activity compared to the un-inoculated diet. The free radical scavenging activities were comparatively higher in diet 2 than in control diet and diet 1. Control diet showed the less value of free radical scavenging activity, and it may be due to the absence of inoculum. In fact, many authors have reported an increase of antioxidant activities during fermentation in various plant-based foods. Wang et al. [26] reported that fermentation increased the phenolic and flavonoid contents during the fermentation by 2 food-grade bacteria (Bacillus subtilis and Lactobacillus plantarum) of 4 cereals (specifically adlay, chestnut, lotus seed, and walnut). These results suggest that the fermentation process enables cerealbased food with enhanced antioxidant capacities to contribute to the health and nutritional improvements in consumers [26].

The ability of fermentation to improve antioxidant activity is primarily due to an increase in the amount of phenolic compounds and flavonoids during fermentation. The mechanism of this process is because microbial enzymes, such as glucosidase, amylase, cellulase, chitinase, inulinase, phytase, xylanase, tannase, esterase, invertase or lipase produced by fermentation can hydrolyze glucosides, and break down plant cell walls or starch [27]. These enzymes play a role in disintegrating the plant cell wall matrix and consequently facilitating the flavonoids extraction [28].

Antioxidant activity during fermentation is also affected by the $\mathrm{pH}$. In fact, $\mathrm{pH}$ is one of the most important environmental parameters affecting food fermentation. $\mathrm{pH}$ is closely related to microbial growth and the structural changes in phytochemicals during fermentation [28]. Borkowski et al. [29] have reported that $\mathrm{pH}$ is a dominant factor in the radical scavenging capacity of wine anthocyanins, as an increase in $\mathrm{pH}$ often increases the capacity for radical scavenging.

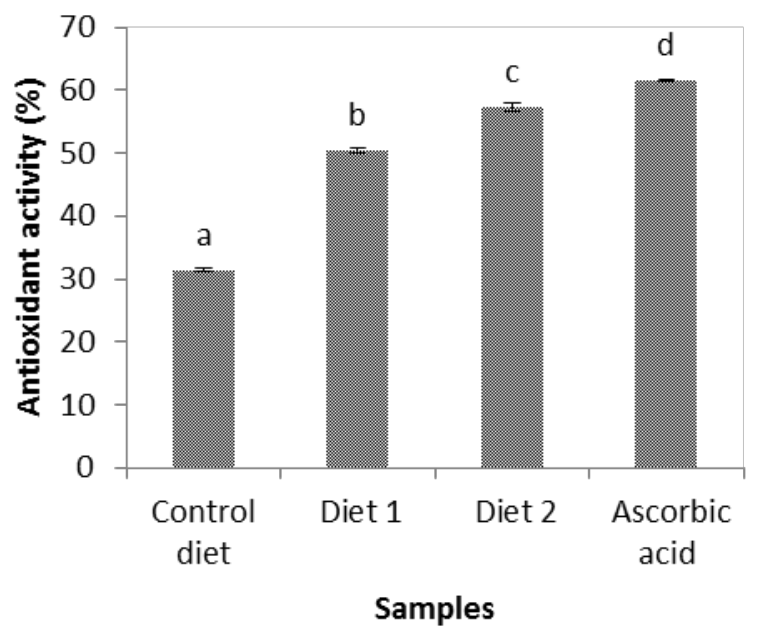

Data are means with standard deviations of triplicate values. Values not sharing a common superscript differ significantly.

Figure 3. Effects of Lc. lactis sp. on antioxidant activity of diets 


\subsection{Proximate Composition}

The macronutrient composition of the three fermented diet samples is presented in Table 3.

Table 3. Proximate composition (g/100g dry weight matter) of fermented diet samples

\begin{tabular}{lccc}
\hline Parameters /100g & Control diet & Diet 1 & Diet 2 \\
\hline Moisture (g) & $5.87 \pm 0.14^{\mathrm{a}}$ & $4.88 \pm 0.32^{\mathrm{b}}$ & $4.40 \pm 0.42^{\mathrm{b}}$ \\
Ash (g) & $3.64 \pm 0.90$ & $3.27 \pm 0.75$ & $3.18 \pm 0.61$ \\
Crude protein (g) & $20.43 \pm 1.05^{\mathrm{a}}$ & $26.81 \pm 0.84^{\mathrm{b}}$ & $27.91 \pm 0.75^{\mathrm{b}}$ \\
Fat (g) & $4.91 \pm 0.71$ & $5.22 \pm 0.84$ & $5.46 \pm 0.65$ \\
Crude fiber (g) & $3.80 \pm 0.66^{\mathrm{a}}$ & $2.64 \pm 0.54^{\mathrm{b}}$ & $2.41 \pm 0.58^{\mathrm{b}}$ \\
Carbohydrate (g) & $61.35 \pm 0.78^{\mathrm{a}}$ & $57.18 \pm 1.02^{\mathrm{b}}$ & $56.91 \pm 0.91^{\mathrm{b}}$ \\
Total energy (Kcal/100g) & $371.31 \pm 4.57^{\mathrm{a}}$ & $382.94 \pm 5.00^{\mathrm{b}}$ & $388.42 \pm 4.16^{\mathrm{b}}$ \\
\hline
\end{tabular}

Data are means with standard deviations of triplicate values. Values not sharing a common superscript differ significantly.

\subsubsection{Moisture Content}

The moisture content of the complementary diet formulations ranged between $4.40 \pm 0.42$ to $5.87 \pm 0.14 \mathrm{~g}$ The highest moisture content was recorded in control diet. This could be explained by the water binding capacity of control diet which was low compared to those of inoculated diets. Free water was more in that diet. The low moisture content of food samples is desirable for extending the shelf life of food products while high moisture contents in food samples encourage the growth of microorganisms; hence it leads food spoilage [30].

\subsubsection{Ash}

Results of ash content showed that values in inoculated fermented diets were slightly lower, ranging from $3.18 \pm$ 0.61 to $3.27 \pm 0.75 \mathrm{~g}$ compared to those in control diet which was $3.64 \pm 0.90$ g. No significant difference $(p<0.05)$ was observed between the three samples. The decrease in ash content observed in this study could be attributed to general activities of the fermenting microorganisms that by enzymatic activity could break down most of these components into their absorbable forms [31].

\subsubsection{Crude Protein}

Crude protein content ranged from $20.43 \pm 1.05$ to $27.91 \pm 0.75 \mathrm{~g}$ in all the fermented samples. Crude protein content significantly increased $(\mathrm{p}<0.05)$ in inoculated diets when compared to the control diet. Results showed a slight increase in the amount of crude protein in inoculated fermented diets although statistical analysis of data showed no significant difference $(p<0.05)$ between these diets. The increase in protein content in inoculated diets may be attributed to the increase in nitrogen content released when microorganisms used carbohydrates for energy [32]. In another way, it may also be attributed to the ability of these microbes to synthesize some amino acids [33]. The result is similar to that of Onilude et al. [34] who reported that fermentation of blends with mixture of Lactobacillus plantarum and Saccharomyces cerevisiae increased the protein value of weaning food and in agreement with the report by Wakil and Kazeem [29] which indicated that fermentation of sorghum-cowpea blends with the mixture of L. plantarum and S. cerevisiae increased the protein value of weaning food. Proteins are important both in quantity and quality, for rapid growth and development of a child. Inadequate intakes of protein at early childhood could lead to Protein Energy Malnutrition (PEM), which, when severe, may cause death or increase the risk of illness and mortality at childhood where infections such as measles and those causing diarrhea can occur [35]. In this study the crude protein content values were superior to the required daily allowance for protein contents in the complementary foods which are ranged from $7.5-11.3$ for $6-11$ months and 6.7-10.8 for 12-23 months [36].

\subsubsection{Crude Fat}

The crude fat contents of all the three fermented diets were low in all cases; they ranged from $4.91 \pm 0.71$ to $5.46 \pm 0.65 \mathrm{~g}$. These values were very low compared to those recommended by Lutter and Dewey [36] for complementary food which should be within 11.7 to 13.7 g/100g for ages 6-11 and 12-23 months respectively. In fact, mungbean, red kidney beans, irish potato and papaya fruit are low sources of fat. The slight increase in fat content of the inoculated fermented samples may be attributed to the increasing activities of lipolytic enzymes, which hydrolyzed fat to glycerol and fatty acid [37]. These results were contrary to those found by Wakil and Kazeem [29] who reported a fat decreasing after fermentation of sorghum-cowpea blends with the mixture of L plantarum and S. cerevisiae.

\subsubsection{Crude Fiber}

The results showed that the crude fiber content ranged from $2.41 \pm 0.58$ to $3.80 \pm 0.66 \mathrm{~g}$. The lowest values were obtained in inoculated diets. There was a significant decrease in crude fiber content $(\mathrm{p}<0.05)$ in inoculated diets when compared to the control diet. The reduction of crude fiber content might be due to enzymatic degradation of the fibrous material during fermentation by Lc. lactis sp. The low crude fiber content is nutritionally appreciated because it traps less protein and carbohydrates [38]. The crude fiber content of infant foods is expected to be low since it helps in keeping children safe, considering the appetite they have to consume more to get satisfied and to meet their daily energy requirement [39]. All the complementary foods processed in this study meet the recommended crude fiber content in complementary food which should be $<5 \%$. [40].

\subsubsection{Carbohydrate}

Results indicated that there was a significantly decreased amount of carbohydrate $(p<0.05)$ between the control diet and inoculated diets. The values ranged from $56.91 \pm 0.91$ to $61.35 \pm 0.78$ g. Statistical analysis showed no significant difference between the two inoculated diets $(\mathrm{p}<0.05)$. The lowest value recorded in inoculated diets may be due to the growth of Lc. lactis sp. strain in the medium, because of bacteria growth microbial activity required energy and nutrient for their metabolism, hence a decrease in carbohydrates, which was the main source of energy. This result was in agreement with those found by Abdulkadir and Danjuma [41] who observed that the spontaneously fermented sorghum soya, bean and tiger nuts blends had the highest carbohydrates content compared to the inoculated blends. A similar observation 
was reported after fermentation of complementary foods formulated from pumpkin seeds, amaranth, finger millet and sorghum grains [42]. All diets processed in this work did not meet the carbohydrate content recommended by WHO/FAO [40] in the complementary food ( $\geq 65 \mathrm{~g} / 100 \mathrm{~g})$.

\subsubsection{Energy}

There was a significant increased $(\mathrm{p}<0.05)$ of total energy in inoculated diets when compared to the control diet. The energy content of all the fermented diet samples was ranged between $371.31 \pm 4.57$ and $388.42 \pm 4.16 \mathrm{kcal} / 100 \mathrm{~g}$. The highest energy content (388.42 $\pm 4.16 \mathrm{kcal}$ ) was observed in diet 2. These results were less than those reported after the fermentation of sorghum/soybean and maize/soybean blends which were ranged from 442.46 to $430.57 \mathrm{kcal} / 100 \mathrm{~g}$ [43]. The new energy requirements are 615, 686 and 894 $\mathrm{kcal} / \mathrm{d}$ for ages 6-8, 9-11 and 12-24 months, respectively [44]. Average human milk energy intakes in developing countries are $413 \mathrm{kcal}$ for infants aged 6-8, 379 kcal for infants aged from 9-11 and 346 kcal for young children aged 12-23 months [45]. Therefore, the energy requirements from diet 2 were 226.58, 297.58 and 505.58 kcal for ages 6-8, 9-11 and 12-23 months, respectively.

\subsubsection{Micronutrients Composition}

Table 4. Mineral composition (g/100g dry weight matter) of fermented foods samples

\begin{tabular}{|c|c|c|c|}
\hline Minerals (mg/100g) & Control diet & Diet 1 & Diet 2 \\
\hline Zinc & $6.44 \pm 0.58$ & $6.58 \pm 0.73$ & $6.63 \pm 0.25$ \\
\hline Iron & $10.40 \pm 0.91^{\mathrm{a}}$ & $12.61 \pm 0.48^{\mathrm{b}}$ & $13.05 \pm 0.72^{\mathrm{c}}$ \\
\hline Potassium & $487.15 \pm 8.01^{\mathrm{a}}$ & $522.51 \pm 9.25^{\mathrm{b}}$ & $578.94 \pm 8.94^{\mathrm{c}}$ \\
\hline Sodium & $57.35 \pm 1.23^{\mathrm{a}}$ & $64.23 \pm 0.97^{\mathrm{b}}$ & $70.71 \pm 1.42^{\mathrm{c}}$ \\
\hline Magnesium & $270.67 \pm 5.28^{\mathrm{a}}$ & $324 \pm 4.19^{\mathrm{b}}$ & $359 \pm 5.01^{\mathrm{c}}$ \\
\hline Calcium & $395.79 \pm 3.96^{\mathrm{a}}$ & $435.08 \pm 4.26^{\mathrm{b}}$ & $495.15 \pm 3.83^{\mathrm{c}}$ \\
\hline
\end{tabular}

Data are means with standard deviations of triplicate values. Values not sharing a common superscript differ significantly.

The mineral composition of fermented diets presented in Table 4 showed that there was a slight increase of most of the mineral contents analyzed in inoculated diets when compared to the control diet.

No significant difference was observed in zinc contents $(\mathrm{p}<0.05)$ of all diet samples. There were ranged from 6.44 \pm 0.58 to $6.63 \pm 0.25 \mathrm{mg} / 100 \mathrm{~g}$. These values were a little bit less than the Recommended Dietary Allowances (RDA): $10-12.5 \mathrm{mg}$ for 6-11 months, $6.7 \mathrm{mg}$ for $12-23$ months and $8.3 \mathrm{mg} / 100 \mathrm{~g}$ for $6-23$ months ages [36].

High iron content was observed in diet $2(13.05 \pm 0.72 \mathrm{~g})$ and low value obtained from control diet $(10.40 \pm 0.91 \mathrm{~g})$. The iron contents in these diet samples were higher than those found by Simwaka et al. [46] in the formulated fermented sorghum-finger millet complementary foods which were ranged from 5.15 to $6.93 \mathrm{mg}$. It has been estimated that complementary foods need to provide $97 \%$ of iron requirements for infants aged 9-11 months [47], and a fortified complementary food should provide a quantity of iron sufficient to ensure that the food at least meets the RDA of $11 \mathrm{mg}$ for infants aged 7-12 months [48].

Magnesium was the highest mineral content in all the fermented diets ranged from $270.67 \pm 5.28 \mathrm{mg}$ to $359 \pm$ $5.01 \mathrm{mg} / 100 \mathrm{~g}$. These values obtained were very higher than the RDA which is 100-150 mg for infants aged 9-11 months, $67-100 \mathrm{mg}$ for $12-23$ months and $80-120 \mathrm{mg}$ for 6-23 months.

Calcium and Sodium significantly $(\mathrm{p}<0.05)$ increased in fermented diets in relation to the concentrations of $L c$. lactis sp. at the end of the fermentation. Diet 2 presented the highest amount of these minerals. This observation indicated that diet 2 would serve as a good source of minerals.

Potassium content decreased in inoculated fermented food, and it may be related to the utilization of this mineral by Lc.lactis sp. during growth.

Fermentation is well known to increase minerals and amino acid levels in food samples. It degrades antinutritional factors like phytates and leads to the availability of calcium, magnesium, phosphorus, zinc, and iron [49]. These results were in agreement with those reported by Adegbehingbe [50] in the effect of single starter cultures on the mineral contents of fermenting 'ogwo,' a fermented gruel from sorghum-Irish potato mixture. However, these results were not in agreement with the study of Tufa et al. [43] in which the authors found that fermentation significantly decreased the calcium, iron and zinc value $(\mathrm{p}<0.05)$ in formulated food samples.

\section{Conclusion}

At the end of this study, it was observed that the fermentation of food by Lc. lactis sp. significantly improves the nutritional value of formulated diets by increasing the protein, fat, mineral contents and decreasing the crude fiber and carbohydrate. High protein content was observed in diet 2. This diet may be recommended as desirable for solving the problem of protein deficiency observable at childhood ages in developing countries. It is found that fermentation process using starter culture is a promising processing method for preparing nutritious and acceptable complementary food.

Relying on the result of the study, the researcher recommended the adding of some drops of palm oil to increase the fat content before giving food to the children.

\section{Acknowledgements}

This work was supported by the Council of Scientific and Industrial Research (CSIR), India, and The World Academy of Sciences (TWAS) for the advancement of science in developing countries (CSIR- TWAS). FR number: 3240275041

\section{Conflict of Interest}

None declared.

\section{References}

[1] Pemunta, N.V. and Fubah, M.A, "Socio-cultural determinants of infant malnutrition in Cameroon”, Journal of Biosocial Science, 1-26. April 2014. 
[2] UNICEF. "State of the World's Children. Child Survival". UNICEF, New York, 2008. Available:

http://www.unicef.org/sowc08/docs/sowc08.pdf.[Accessed March.12, 2016]

[3] WHO/UNICEF. "Child Growth Standards and the Identification of Severe Acute Malnutrition in Infants and Children”, A joint statement by the World Health Organization and the United Nations Children's Fund, 2009.

[4] UNICEF. "Humanitarian Action Update. Children in Crisis in the Sahel. Burkina Faso, Cameroon, Chad, Gambia, Mali, Mauritania, Niger, Nigeria, Senegal”, 2012. Available:

http://www.unicef.org/hac2012/files/UNICEF_Humanitarian_Acti on_Update_Sahel_June_2012.pdf. [Accessed Jan.7, 2017].

[5] Kengne, N.A.P., Ngongi, J.L. and Oben, J.E, "Factors associated with breast feeding as well as the nutrition status of infants (0-12) months: An epidemiological study in Yaoundé, Cameroon”, Pakistan Journal of Nutrition, 6(3). 259-63. May-June 2007.

[6] Grajek, W., Olejnik, A. and Sip, A, "Probiotics, prebiotics and antioxidants as functional foods", Acta Biochimica Polonica, 52(3). 665-71. August 2005.

[7] Rivera-Espinoza, Y. and Gallardo-Navarro, Y, "Non-dairy probiotic products”, Food Microbiology, 27: 1-11. Febuary 2010.

[8] Gardiner, G.E, Bouchier, P., O’Sullivan, E., Kelly, J., Kevin, C.J, Fitzgerald, $\mathrm{G}$ et al. "A spray-dried culture for probiotic Cheddar cheese manufacture”, International Dairy Journal, 12(9). 749-56. September 2002.

[9] Charalampopoulos, D., Wang, R., Pandiella, S.S. and Webb, C, "Application of cereals and cereal components in functional foods: A review”, International Journal of Food Microbiology, 79 (1/2). 131-141. November 2002.

[10] Enwa, F.O., Beal, J. and Arhewoh, M.I, "Effect of maize and bacteria starter culture on maize fermentation process", International Journal of Biomedical and Advance Research, 2(11). 561-67. November 2011.

[11] Ekwem, O.H, "Isolation of antimicrobial producing lactobacilli from akamu (A Nigerian fermented cereal gruel)", African Journal of Microbiology Research, 8(7). 718-20. August 2014

[12] Ihekoronye, A.I, and Ngoddy, P.O, "Integrated food science and technology for the tropics”. London: Macmillan, 1985.

[13] Li, W., Mutuvulla, M., Chen, X., Jiang, M. and Dong, M, "Isolation and identification of high viscosity-producing lactic acid bacteria from a traditional fermented milk in Xinjiang and its role in fermentation process", European Food Research and Technology, 235. 497-505. July 2012.

[14] Isanga, J. and Zhang, G, "Production and evaluation of some physicochemical parameters of peanut milk yoghurt", LWT Food Science and Technology, 42. 1132-1138. July 2009.

[15] AOAC, "Official Methods of Analysis. Association of Official Analytical Chemists" 18th ed. Washington, D.C, 2005.

[16] Sena, L.P., Van der jagt, D.J., Rivera, C., Tsin,A.C.T., Muhamadu, I., Mahamadou, O., Millson, M., Pastuszyn A. and Glew, R.H, "Analysis of nutritional components of eigt famine foods of the republic of Niger”, Plant Foods for Human Nutrition, 52. 17-30. Febuary 1998.

[17] WHO/UNICEF, "Complementary feeding of young children in developing countries: A review of current scientific knowledge", WHO/NUT/98.1 Geneva: World Health Organization, 1998.

[18] Byaruhanga, Y.B., Bester, B..H. and Watson, T.G, "Growth and survival of Bacillus cereus in mageu, a sour maize beverage", World Journal of Microbiology and Biotechnology, 15(3). 329-333. June 1999.

[19] Muyanja, C.M.B.K., Narvhus, J.A., Treimo, J. and Langsrud, T, "Isolation, characterisation and identification of lactic acid bacteria from bushera: a Ugandan traditional fermented beverage", International Journal of Food Microbiology, 80. 201-210. Febuary 2003.

[20] Rozada-Sánchez, R., Sattur, A.P., Thomas, K. and Pandiella, S.S, "Evaluation of Bifidobacterium spp. for the production of a potentially probiotic malt-based beverage", Process Biochemistry, 43. 848-854. August 2008.

[21] Kim, N.J., Jang, H.L. and Yoon, K.Y, "Potato Juice Fermented with Lactobacillus casei as a Probiotic Functional Beverage", Food Science and Biotechnology, 21(5). 1301-1307. October 2012.

[22] Kailasapathy, K. and Chin, J, "Survival and therapeutic potential of probiotic organisms with reference to Lactobacillus acidophilus and Bifidobacterium spp”. Immunology and Cell Biology, 78(1). 80-88. Febuary 2000
[23] Ferragut, V., Cruz, N.S., Trujillo, A., Guamis, B. and Capellas, M, "Physical characteristics during storage of soy yogurt made from ultra-high pressure homogenized soymilk". Journal of Food Engineering, 92(1). 63-69. May 2009.

[24] Folkenberg, D.M., Dejmek, P., Skriver, A. and Ipsen R, "Relation between sensory texture properties and exopolysaccharide distribution in set and in stirred yoghurts produced with different starter cultures”, Journal of Texture Studies, 36(2). 174-189. April 2005.

[25] Li, C., Li, W., Chen, X., Feng, M., Rui, X., Jiang, M. and Dong, M, Microbiological, physicochemical and rheological properties of fermented soymilk produced with exopolysaccharide (EPS) producing lactic acid bacteria strains”. LWT - Food Science and Technology, 57(2). 477-485. July 2014

[26] Wang, C-Y., Wu, S-J. and Shyu, Y-T, "Antioxidant properties of certain cereals as affected by food-grade bacteria fermentation", Journal of Bioscience and Bioengineering, 117(4). 449-56. April 2014.

[27] Cai, S., Wang, O., Wu, W., Zhu, S., Zhou, F., Ji, B., Gao, F., Zhang, D., Liu, J. and Cheng, Q, "Comparative study of the effects of solid-state fermentation with fhree filamentous fungi on the total phenolics content (TPC), flavonoids, and antioxidant activities of subfractions from oats (Avena sativa L.)”. Journal of Agricultural and Food Chemistry, 60(1). 507-513. January 2012.

[28] Hur, S.J., Lee, S.Y., Kim, Y-C., Choi, I. and Kim, G-B, "Effect of fermentation on the antioxidant activity in plant-based foods". Food Chemistry, 160. 346-56. October 2014.

[29] Borkowski, T., Szymusiak, H., Gliszczynska-Swiglo, A., Rietjens, I.M.C.M. and Tyrakowska, B, "Radical scavenging capacity of wine anthocyanins is strongly $\mathrm{pH}$-dependent”, Journal of Agricultural and Food Chemistry, 53(14). 5526-34. July 2005.

[30] Temple, V., Badamosi, E., Ladeji O., Solomon, M. and Gowok, H, "Proximate Chemical Composition of three locally formulated complementary foods in West African", Journal of Biological Sciences, 5. 134-143. 1996.

[31] Wakil, S.M. and Kazeem, M.O, "Quality assessment of weaning food produced from fermented cereal-legume blends using starters”, International Food Research Journal, 19(4). 1679-1685. Febuary 2012

[32] Onyango, C., Noetzold, H., Ziems, A., Hofmann, T., Bley, T. and Henle, T, "Digestibility and antinutrient properties of acidified and extruded maize-figer millet blend in the production of Uji”, LWTFood Science and Technology, 38(7). 697-707, November 2005.

[33] Sanni, A.I., Onilude, A.A. and Ibidapo, O.T, "Biochemical composition of infant weaning food fabricated from fermented blends of cereal and soybean”, Food Chemistry, 65(1). 35-39. April 1999.

[34] Onilude, A.A., Sanni, A.I. and Ighalo, M.I, "Process Upgrade and the Microbiological, Nutritional and Consumer Acceptability of Infant Weaning Food from Fermented Composite Blends of Cereals and Soybean", Journal of Food, Agriculture and Environment, 2, 64- 68. Juin 2004.

[35] WHO (World Health Organization), "Vitamin A supplementation in infants and children 659 months of age", 2011. Available: http://whqlibdoc.who.int/publications/2011/9789241501767_eng.p df.

[36] Lutter, C.K. and Dewey, K.G, "Proposed Nutrient Composition for Fortified Complementary Foods", The journal of Nutrition, 133(1), 3011-3020. January 2003.

[37] Lheke, E., Oshodi, A., Omoboye, A.A. and Ogunlalu, O, "Effect of fermentation on the physicochemical properties and nutritionally valuable minerals of locust bean (Parkia biglobosa)", American Journal of Food Technology, 12. 379-384. December 2017.

[38] Balogun, A.M. and Fetuga, B.L, "Chemical composition of some underexploited leguminous crop seeds in Nigeria", Journal of Agricultural and Food Chemistry, 34. 189-192. March 1986.

[39] Eka, O. and Edijala, J, "Chemical composition of some traditionally prepared Nigerian foods". Nigerian Journal of Science, 6, 157-62. 1972.

[40] WHO/ FAO, "Human vitamin and mineral requirements", Report of a joint FAO/WHO consultation, Bangkok, Thailand. Rome: Food and Agriculture Organization of the United Nations (FAO) and World Health Organization (WHO), 2004.

[41] Abdulkadir, M. and Danjuma, J.B, "Microbial profile and nutritional quality during the fermentation of cereal based weaning food fortified with soya bean and tiger nut using starter culture”, world scientific news, 24. 103-115. August 2015. 
[42] Simwaka, J.E., Chamba, M.V.M., Huiming, Z., Masamba, K.G. and Luo, Y, "Effect of fermentation on physicochemical and antinutritional factors of complementary foods from millet, sorghum, pumpkin and amaranth seed flours”, International Food Research Journal, 24(5). 1869-1879. October 2017.

[43] Tufa, M.A., Urga, K., Weledesemayat, G.T. and Mitiku, B.G, "Development and Nutritional Assessment of Complementary Foods from Fermented Cereals and Soybean”, Journal of Food Science and Nutrition, 2. 014. November 2016.

[44] Dewey, K. G. and Brown, K. H, "Update on technical issues concerning complementary feeding of young children in developing countries and implications for intervention programs”. Food and Nutrition Bulletin, 24(1). 5-28. March 2003.

[45] WHO, "Complementary feeding of young children in developing countries: a review of current scientific knowledge”, WHO/NUT/98.1, Geneva, Switzerland. 1998.

[46] Simwaka, J.E., Huiming, Z. and Masamba, K.G, “Amino acid profile, mineral, pasting, thermal and protein solubility characteristics of sorghum-finger millet based complementary food as affected by fermentation”, Journal of Academia and Industrial Research, 3(10). 504-510. March 2015.

[47] Dewey, K.G, "Nutrition, growth, and complementary feeding of the breastfed infant", Pediatric Clinics of North America, 48. 87-104. Febuary 2001.

[48] Lynch, S. and Stoltzfus, R, "Iron and ascorbic acid: proposed fortification levels and recommended iron compound”, Journal of Nutrition, 133. 2979-2984. Febuary 2003.

[49] Greffeuille, V., Polycarpe Kayodé, A.P., Icard-Vernière, C., Gnimadi, M., Rochette, I. and Mouquet-Rivier, C, "Changes in iron, zinc and chelating agents during traditional African processing of maize: Effect of iron contamination on bioaccessibility”, Food Chemistry, 126(4). 1800-1807. June 2011.

[50] Adegbehingbe, K.T, "Effect of starter cultures on the anti-nutrient contents, minerals and viscosity of ogwo, a fermented sorghumIrish potato gruel”, International Food Research Journal, 22(3). 1247-1252. November 2015. 